\title{
Using Positive Youth Development Constructs to Design a Money Management Curriculum for Junior Secondary School Students in Hong Kong
}

\author{
Patrick S. Y. Lau, ${ }^{1}$ C. M. Lam, ${ }^{2}$ Ben M. F. Law, ${ }^{3}$ and Y. H. Poon ${ }^{2}$ \\ ${ }^{1}$ Department of Educational Psychology, The Chinese University of Hong Kong, \\ Hong Kong \\ ${ }^{2}$ Department of Social Work, The Chinese University of Hong Kong, Hong Kong \\ ${ }^{3}$ Department of Social Work and Social Administration, The University of Hong Kong, \\ Hong Kong
}

Received 1 November 2010; Revised 28 February 2011; Accepted 16 August 2011

Academic Editor: Joav Merrick

\begin{abstract}
This paper aims to discuss the relationships between the selected positive youth development constructs and the enhancement of Hong Kong junior secondary school students' money management skills, values, and attitudes. Various issues of money management of adolescents are reviewed. These issues include the need for money management programs for adolescents, the content and coverage of an appropriate money management program, and its relationships with the selected positive youth development constructs. The curriculum units for secondary 3 students are taken as examples to illustrate the design of the program. It is believed that promoting cognitive competence, self-efficacy, and spirituality could be an effective way to enhance students' money management skills, values, and attitudes, thus preparing them better for facing the financerelated issues in life.
\end{abstract}

KEYWORDS: Chinese adolescents, positive youth development, money management, success 


\section{INTRODUCTION}

Catalano et al. [1] reviewed 77 programs for promoting positive youth development and identified 15 common constructs from 25 programs which were regarded as effective. These constructs include behavioral competence, beliefs in the future, bonding, clear and positive identity, cognitive competence, emotional competence, moral competence, prosocial involvement, prosocial norms, recognition for positive behavior, resilience, self-determination, self-efficacy, social competence, and spirituality. This is the framework adopted as the theoretical basis of a positive youth development program entitled "P.A.T.H.S. to Adulthood: A Jockey Club Youth Enhancement Scheme" [2]. The acronym "P.A.T.H.S." stands for "Positive Adolescent Training through Holistic Social Programs." The aims of the project are to promote positive and holistic development of junior secondary school students (secondary 1 to secondary 3 ) in Hong Kong.

The Hong Kong Jockey Club Charities Trust first allotted a huge sum of HK\$400 million in 2005 to launch the project. In the Tier 1 program of the project, a total of 120 teaching units were designed to promote the 15 positive youth development constructs among the junior secondary school students. In 2009, The Hong Kong Jockey Club Charities Trust earmarked another large sum of HK\$350 million to support the project for a second cycle. To strengthen the Tier 1 program of the project, another 60 new teaching units were designed in response to five developmental issues identified in adolescents in Hong Kong. The five developmental themes are substance abuse, sexuality issues, internet addiction, bullying, and money and success. One should note that the design of these 60 new units is for promoting the psychosocial competence of adolescents rather than assisting them to solve the developmental problems only [3], although the latter would probably happen. Among these 60 newly designed units, 9 of them are related to the theme "money and success" with 2 units, 4 units, and 3 units for secondary 1, 2, and 3 students, respectively.

In this paper, by reviewing the literature on the need for a money management program for promoting adolescents' money management skills, the financial socialization process of adolescents, and what students should learn in such a program, we are to discuss the relationships between the selected positive youth development constructs (cognitive competence, self-efficacy, and spirituality) and the design of a money management program. The curriculum units for secondary 3 students are taken as examples to illustrate the program design.

\section{THE NEED FOR MONEY MANAGEMENT TRAINING PROGRAMS FOR YOUTHS AND ADOLESCENTS}

Only $31 \%$ of the participants expressed that they always pay the credit card bill in full to avoid interest charges in a group of young Australian workers [4]. This implies that most of the young workers would choose to pay a large sum of interest for their credit activities. In the United States of America, it was reported by Godfrey [5] that about 150,000 aged 18-24 young adults were declared bankrupt in 2005. She described the severe situation as "more go bankrupt than graduate from college" (page 22) and argued for more money management programs to be implemented in educational settings.

One may ask if youths in Hong Kong get into financial trouble severely. The situation looks similar to that we have found in western communities. A newspaper reporter, Cheng [6], reported that in Hong Kong, among five indebted youths, one would be a university student. This implies that the financial skills of the local youths may not match their level of education. The spokesman of a family counselling centre run by Tung Wah Group of Hospitals expressed that there were altogether 145 youth indebted cases reported to their centre within the period from January to May in 2010. More than $80 \%$ of these reported cases involved a debt of over 80,000 Hong Kong dollars. Among the indebted cases of university students, most of the parents would shoulder the debts for their children. Some parents even asked for early retirement and paid back the debts by using the retirement fund [6].

Furthermore, Cheng [6] expressed that overdraft from credit card accounts was the most common consumption behavior of many Hong Kong youths. Likewise, Yip and his associates [7] found that using credit cards was the main source of the debts in Hong Kong. If the interest rate charged on 
credit cards in Hong Kong, as reported by Chan [8], is the highest in the world, this would probably result in severe financial troubles of the young overspenders. Besides, Chau et al. [9] reported that among 812 university students in Hong Kong, only 3.2\% and 5.3\% expressed that they knew a lot and quite a lot of the terms of their credit card, respectively, while $27 \%$ confessed that they knew very little or nothing of these terms. As a matter of fact, $20.5 \%$ of the respondents reported the financial concerns had obviously affected their academic work. These findings add up to an impression that the situation of financial debts of the youths in Hong Kong is quite severe. In response to the rising financial troubles found among youths and adolescents, we therefore support the argument of Godfrey [5] that there should be an increasing need for money management curriculum to be implemented in schools.

Regarding the effectiveness of the money management education in schools, Mandell and Klein [10] found that high school students who had taken a money management course did not consider themselves to be more saving oriented and did not show better financial behavior than those who had not taken the course. The authors explained that the ineffectiveness of the program might be due to sample bias because only 79 respondents from one school system were involved and therefore care should be taken in interpreting the results which might be different if the sample size was larger and more diversified. Nevertheless, more positive findings were revealed from other studies. Mandell [11] reported that high school students who played a stock market game in a course were found to be significantly more financial literate than those who did not. Mandell and Klein [12] asserted that if students were motivated to understand the importance of money management skills to their future life, they would do better in the program. Koenig [13] designed a financial literacy course by modifying an existing curriculum according to the personal experience of a group of young offenders in a correctional education setting. Results showed that by taking the financial literacy course, the young offenders significantly gained more knowledge and skills of money management. In addition, Stanger [14] found that those who had participated in mandatory money management education in high schools showed better saving habits than those who had not. In summary, if issues like interactivity, enjoyment, motivation, appropriate content knowledge, and the needs of participants can be taken into consideration in designing the money management program, positive effects of improving students' financial literacy are expected to be seen.

Moreover, it has been found that how money is being spent by young people might be an important factor behind drug abuse. Findings showed that there is a positive relationship between the amount of money received and the rates of drug use among the young people in Northern Ireland [15]. This implies that money management education could be an effective way in fighting substance abuse among adolescents.

Other than from schools, children could learn skills of money management from their parents and family. This might involve a process of socialization which mainly occurs in the family. Danes [16] pointed out that the literature related to financial socialization of children mainly come from the literature of consumer socialization which is defined as the "process by which young people acquire skills, knowledge, and attitudes relevant to their effective functioning as consumers in the marketplace" [17, page 2]. Danes [16] expanded this definition from "learning to effectively function in the marketplace" (page 128), to "acquiring and developing values, attitudes, standards, norms, knowledge, and behaviors that contribute to the financial viability and wellbeing of the individual" (page 128) in her study on parental perceptions of children's financial socialization. Findings showed that most parents agreed that children at the age from 12 to 14 and from 15 to 17 were ready to be involved in family financial activities. Moreover, in the eyes of parents, children at the age from 18 were ready for credit experiences.

In response to these findings of parents' perceptions on adolescents' readiness to be involved in financial activities, there seems to be a need for money management education for students from secondary 1 (grade 7) to secondary 3 (grade 9). Junior forms would be a suitable period to provide adolescents with financial education to assist them to develop appropriate attitudes and managing skills towards money, thus preparing them better to face the financial issues which would probably occur later in their lives. 


\section{WHAT ADOLESCENTS SHOULD LEARN FROM MONEY MANAGEMENT PROGRAMS}

Atkinson et al. [18] studied the levels of financial capability among a group of 5,328 subjects in the United Kingdom. They found that financial capability could be conceived as encompassing four domains: managing money, planning ahead, choosing products, and staying informed. "Managing money" is the ability to manage one's available means to make ends meet (e.g., to pay bills on time, etc.) and to keep track of one's expenses. "Planning ahead" is the ability to plan for one's future financial commitments, especially the substantial ones. "Choosing products" means the knowledge, the attitudes, and the behavior and confidence to select appropriate financial products. "Staying informed" is the ability to get help, information, and advice when one is facing financial matters.

Likewise, Kwok and Yung [19] pointed out that financial capability should cover four areas including financial understanding, financial competence, financial enterprise, and financial responsibility. "Financial understanding" is the knowledge a person has about his/her income, expenses, savings, investments, risks, debts, and so forth. "Financial competence" is a person's ability to manage his/her finance in daily life, for example, to keep track of expenses, to prepare short-term and long-term financial commitments, to collect information about finance, and so forth. "Financial enterprise" is a person's ability to effectively and creatively plan for his/her money spending activities through evaluation, analysis, and decision making. "Financial responsibility" is a person's attitude and sense to consider the societal, moral, cultural, or financial influences of his/her financial activities on others.

In addition, Danes [16] emphasized that along the process of financial socialization, children are expected to acquire and develop attitudes, knowledge, and behaviors towards money that could contribute to their financial viability. Along this line of thought and the views of Atkinson et al. [18] and Kwok and Yung [19], the money management training program for adolescents should not only focus on promoting their effective money management skills but also developing adolescents' appropriate values and attitudes towards how money should be spent.

Furthermore, in designing financial curriculum units, one should also consider three criteria of the best practices in financial education including (1) teachable moments, (2) teaching methods, and (3) program effectiveness evaluation [20]. For teachable moments, according to Dane's findings of parents' perceptions on adolescents' readiness to be involved in financial activities [10], which we have discussed before, secondary 1 (grade 7) to secondary 3 (grade 9) would be a suitable period to provide adolescents with financial education. For teaching methods, Kezar and Yang [20] and Mandell [11] emphasized that active and experiential techniques could engage students directly with the content. Similar to our usual practice in designing the P.A.T.H.S. curriculum units, experiential and interactive teaching activities have been adopted in designing the new units. For program effectiveness evaluation, we have developed a comprehensive evaluation plan to evaluate the entire program of the Project P.A.T.H.S. [21].

In sum, according to the above documents reviewed in this paper, a money management program should provide students with training in knowledge, skills, and values and attitudes related to finance. Understanding the different kinds of financial products and their characteristics are examples of "knowledge"; saving, budgeting, and planning are examples of "skills"; whereas considering the purpose in life and meaning of success in spending or earning money, career, and life planning, and how to spend money in a more meaningful way are examples of "values and attitudes." The program should be implemented among students at teachable moments by adopting active and experiential teaching strategies. Methods for evaluating program effectiveness should also be carefully designed.

\section{RELATIONSHIPS BETWEEN POSITIVE YOUTH DEVELPOPMENT CONTRUCTS AND MONEY MANAGEMENT PROGRAM FOR ADOLESCENTS}

By reviewing the 120 curriculum units of Project P.A.T.H.S. (I), we have identified 19 units which are related to "money and success" with 5, 4, and 10 units for secondary 1, 2, and 3, respectively. This explains 
the reason why we arrange the 9 newly developed units related to money and success into a 2-4-3 pattern for secondary 1, 2, and 3. This will total to $7 \mathrm{~S} 1$ units, $8 \mathrm{~S} 2$ units, and $13 \mathrm{~S} 3$ units. Since S3 students may have more needs for financial knowledge and skills, more units having been designed for them in this regard is understandable. The aims and learning targets of the 19 units in P.A.T.H.S. (I) are summarized in Table 1.

Generally speaking, knowledge, skills, and values related to money management and concepts of success are covered in these 19 units. It is found that in the secondary 1 and 2 curriculum, the units are mainly about promoting "managing oneself and one's wealth" while in the secondary 3 curriculum, the units are mainly about promoting "helping others." Among these 19 units, 8 positive youth development constructs are involved including Beliefs in the Future, Cognitive Competence, Healthy Identity, Resilience, Social Competence, Self-Determination, Self-Efficacy, and Spirituality. Spirituality (6 units) and SelfEfficacy (4 units) seem to be the two most appropriate constructs in designing education curriculum related to money and success because they are the most frequently used ones in designing the related units in P.A.T.H.S. (I). In addition, promoting students' knowledge about the financial products and the consequence of using these products may involve students' critical thinking skills which is a major concept of Cognitive Competence. Therefore, these 3 positive youth development constructs, including Cognitive Competence, Self-Efficacy, and Spirituality, are selected to be the basis for designing units related to money management education for junior secondary school students in the second phase of Project P.A.T.H.S. The relationship between the selected positive youth constructs and the design of money management teaching units is elaborated as follows.

Through introducing the curriculum design for enhancing students' cognitive competence as a positive youth development construct, Sun and Hui [22] asserted that the concepts of cognitive competence refer to creative thinking and critical thinking. According to Sternberg and Lubart [23], "creative thinking" focuses on different thinking styles like legislative, global and local, and progressive thinking styles to deal with problems. On the other hand, "critical thinking," according to Ennis [24], comprises reasoning, making inferences, self-reflection, and coordination of multiple views.

In designing the money management curriculum, promoting students' creative thinking could assist them to consider related alternatives and bring out more possible proposals for spending money. In addition, developing students' critical thinking abilities would help them identify errors in their thoughts, make a clever and appropriate financial decision, or choose more suitable financial products. Therefore, skills related to creative thinking and critical thinking should be a focus in the design of related teaching units. This would promote students' ability of managing money, choosing products, financial knowledge, financial enterprise, and financial responsibility.

Besides, enactive attainment, vicarious experience, imaginal experience, social persuasion, and physical and emotional states are the main determinants of positive self-efficacy [25, 26]. Bandura [27] pointed out that the knowledge and experience resulted from these determinants might regulate four psychological processes including the cognitive processes, motivational processes, affective processes, and selection processes to produce the actual performance. The cognitive processes involve "self-appraisal of capabilities, skills, and resources; goal selection; construction of success and failure scenarios in the goal accomplishment processes; generation and selection of problem-solving options; sustaining the necessary attention and functioning for task completion" [28, page 443]. The motivational processes involve three cognitive motivators, namely, attribution, value of the expected outcomes, and the clarity and value of goals. Affective processes refer to a person's arousal threshold and tolerance of negative emotions like anxiety and depression resulted by his/her perception of one's coping abilities. The selection processes refer to a person's selection and creation of physical and social environment to match their perceived capabilities and resources to attain desired outcomes.

Budgeting is an important skill a student should attain from the money management program. The budgeting skills would involve all the four psychological processes related to self-efficacy. When a person is evaluating his/her revenues and expenses, he/she has to set goals of the plan, to consider his/her motivators behind, to deal with the emotions involved, and to select ways or environment to attain the desired outcomes. Therefore, enhancing students' self-efficacy with examples related to budgeting could be a good way 
TABLE 1: Aims and learning targets of P.A.T.H.S. I curriculum units related to "Money and Success."

\begin{tabular}{|c|c|c|c|}
\hline Grade & Unit & Aims & Learning targets \\
\hline \multirow{6}{*}{ S1 } & \multirow{2}{*}{ Yes, I Can! (SE1.2) } & \multirow{2}{*}{$\begin{array}{l}\text { To experience self-efficacy } \\
\text { through enactive attainment }\end{array}$} & To experience success \\
\hline & & & To identify past successes \\
\hline & $\begin{array}{l}\text { Doing it the SMART } \\
\text { Way (SE1.4) }\end{array}$ & $\begin{array}{l}\text { To experience feelings of } \\
\text { self-efficacy through goal } \\
\text { attainment }\end{array}$ & To set feasible goals \\
\hline & $\begin{array}{l}\text { The Dream Train } \\
\text { (SD1.3) }\end{array}$ & $\begin{array}{l}\text { To enhance students' competence } \\
\text { in self-determination by setting } \\
\text { optimal and feasible goals }\end{array}$ & $\begin{array}{l}\text { To master skills in goal setting and goal } \\
\text { adjustment }\end{array}$ \\
\hline & My Favorites? (SP1.1) & $\begin{array}{l}\text { To facilitate students to think } \\
\text { about their life priorities }\end{array}$ & $\begin{array}{l}\text { To reflect on materialistic values and to } \\
\text { weaken them }\end{array}$ \\
\hline & Life Compass (BF1.2) & $\begin{array}{l}\text { To enable students to develop a } \\
\text { belief in the future and to } \\
\text { encourage them to adopt a positive } \\
\text { view in identifying life orientation }\end{array}$ & $\begin{array}{l}\text { To have positive beliefs about the future in } \\
\text { study, family, and peer aspects }\end{array}$ \\
\hline \multirow{6}{*}{ S2 } & $\begin{array}{l}\text { A Career Rhapsody } \\
\text { (SC2.2) }\end{array}$ & $\begin{array}{l}\text { To build up the value that people } \\
\text { of different occupations should be } \\
\text { accorded the same respect }\end{array}$ & $\begin{array}{l}\text { To understand that different occupations } \\
\text { contribute to Hong Kong and should be } \\
\text { respected }\end{array}$ \\
\hline & Living Elsewhere & To encourage students to live a & To understand the plight of the deprived \\
\hline & (SP2.1) & the living condition of the deprived & $\begin{array}{l}\text { To treasure what we have and live a } \\
\text { meaningful life }\end{array}$ \\
\hline & The World of Money & To encourage students to reflect on & To reflect on the meaning of money \\
\hline & (SP & lives & $\begin{array}{l}\text { To understand that material possessions may } \\
\text { not necessarily lead to happiness }\end{array}$ \\
\hline & $\begin{array}{l}\text { The Values of Life } \\
\text { (ID2.1) }\end{array}$ & $\begin{array}{l}\text { To build a positive self-image } \\
\text { through discovering the most ideal } \\
\text { aspects of oneself }\end{array}$ & $\begin{array}{l}\text { To self-encourage and affirm oneself for the } \\
\text { values that one is pursing }\end{array}$ \\
\hline \multirow{6}{*}{ S3 } & $\begin{array}{l}\text { What Will Your } \\
\text { Future Be? (BF3.1) }\end{array}$ & $\begin{array}{l}\text { To assist students to choose a } \\
\text { realistic but optimistic way of life }\end{array}$ & $\begin{array}{l}\text { To adopt a realistic and positive attitude in } \\
\text { exploring future careers }\end{array}$ \\
\hline & $\begin{array}{l}\text { Looking Forward } \\
\text { (BF3.4) }\end{array}$ & $\begin{array}{l}\text { To cultivate students' abilities to } \\
\text { plan for future education and } \\
\text { careers, and to monitor and } \\
\text { motivate their goal-pursuing } \\
\text { behavior }\end{array}$ & $\begin{array}{l}\text { To set up evaluating and rewarding thinking } \\
\text { patterns to strengthen one's perseverance in } \\
\text { the process of goal attainment }\end{array}$ \\
\hline & $\begin{array}{l}\text { Where Does Value } \\
\text { Lie? (SP3.2) }\end{array}$ & $\begin{array}{l}\text { To help students understand life } \\
\text { values from different perspectives }\end{array}$ & $\begin{array}{l}\text { To reflect life values from the stories of } \\
\text { people who have suffered }\end{array}$ \\
\hline & & & To understand the importance of belief in life \\
\hline & Why? (SP3.3) & $\begin{array}{l}\text { To deepen students' understanding } \\
\text { of the meaning of life }\end{array}$ & $\begin{array}{l}\text { To introduce the work and life values of } \\
\text { people who are committed volunteers and to } \\
\text { explore how their beliefs influence their } \\
\text { commitments }\end{array}$ \\
\hline & $\begin{array}{l}\text { The Life Novel } \\
\text { (SP3.4) }\end{array}$ & $\begin{array}{l}\text { To help students search for their } \\
\text { own meanings of life }\end{array}$ & $\begin{array}{l}\text { To integrate and consolidate the content } \\
\text { learned in previous units }\end{array}$ \\
\hline
\end{tabular}


TABLE 1: Continued.

\begin{tabular}{|c|c|c|c|}
\hline Grade & Unit & Aims & Learning targets \\
\hline & $\begin{array}{l}\text { A Contented Heart Is } \\
\text { a Joyful Heart } \\
\text { (RE3.1) }\end{array}$ & $\begin{array}{l}\text { To promote optimism through } \\
\text { positive thinking }\end{array}$ & $\begin{array}{l}\text { To develop an optimistic view and a } \\
\text { contented attitude towards life among } \\
\text { students }\end{array}$ \\
\hline & $\begin{array}{l}\text { Who Is the Richest? } \\
\text { (SE3.1) }\end{array}$ & $\begin{array}{l}\text { To cultivate students' self-efficacy } \\
\text { in wealth management }\end{array}$ & $\begin{array}{l}\text { To understand that successful wealth } \\
\text { management relies on the ability to exercise } \\
\text { self-control and delayed gratification }\end{array}$ \\
\hline & & & $\begin{array}{l}\text { To understand the importance of controlling } \\
\text { desires for unnecessary material things }\end{array}$ \\
\hline & My Dream! My Way! & $\begin{array}{l}\text { To motivate oneself to live } \\
\text { according to one's dreams through }\end{array}$ & $\begin{array}{l}\text { To understand the meaning of dreams and } \\
\text { their importance in life }\end{array}$ \\
\hline & & an appropriate vision of the future & $\begin{array}{l}\text { To identify the personal qualities that help } \\
\text { one overcome environmental constraints and } \\
\text { realize dreams }\end{array}$ \\
\hline & $\begin{array}{l}\text { Siblings of Hong } \\
\text { Kong (SC } 3.2 \text { ) }\end{array}$ & $\begin{array}{l}\text { To establish the vision of } \\
\text { contributing to one's country }\end{array}$ & $\begin{array}{l}\text { To reflect on how we can contribute to China } \\
\text { by learning the lives of people who are } \\
\text { living in a poor condition }\end{array}$ \\
\hline & $\begin{array}{l}\text { The Truth Behind } \\
\text { Advertisements } \\
\text { (CC3.2) }\end{array}$ & $\begin{array}{l}\text { To apply critical thinking in } \\
\text { tackling information promoting } \\
\text { materialism and consumerism }\end{array}$ & $\begin{array}{l}\text { To reflect on what has to be considered } \\
\text { before consumption }\end{array}$ \\
\hline
\end{tabular}

Notes: BF: beliefs in the future, CC: cognitive competence, ID: healthy identity, RE: resilience, SC: social competence, SD: self-determination, SE: self-efficacy, SP: Spirituality.

to develop their abilities of managing money, planning ahead, staying informed, financial competence, financial enterprise, and financial responsibility.

Furthermore, Lau [29] advocated that there are three key elements of spirituality including connectedness to others, personal beliefs and values, and the search for the meaning of life. Among these three, the quest for the meaning of life seems to relate to a person's attitudes towards money management the most. One may do something illegal in order to gain more money for their luxurious living while others may choose to work in the third world or a developing society in order to contribute to others and make one feel more meaningful of one's life. This altruistic decision relates to how the students view "success." Cheung et al. [30] identified 3 conceptions of success among a group of 673 secondary school students including task orientation (belief that success is gaining skill or understanding), collaborative orientation (belief that success is working productively with one or more collaborators), and ego orientation (belief that success is establishing one's competence as superior). It was found that task orientation and collaborative orientation increased with prosocial behaviors like the inclination to help others, to cooperate and share things with others, and to behave in compliance with social norms. Since the relationship between prosocial behaviors and conceptions of success is correlational in nature and the directionality of effects can be from both sides, this could have implications for designing curriculum to promote students' spirituality. For example, stories of altruistic actions could be good teaching materials to guide students to reconsider their thoughts of success and meaning of life.

Danes [16] highlighted the importance of developing an adolescent's attitudes and values towards money in the financial socialization process. This is in line with the focus of "spirituality" as well. Among the important decisions in life, making career choice could be a good platform for students to reflect on their attitudes and values towards money and their conception of success. When a person is planning his/her future career, other than considering the income induced from the job, he/she should consider the values and meaningfulness embedded in the choice as well. Therefore developing students' spirituality would 
TABLE 2: Aims and learning targets of S3 P.A.T.H.S. (II) curriculum units related to "Money and Success."

\begin{tabular}{|c|c|c|}
\hline Unit & Aims & Learning targets \\
\hline $\begin{array}{l}\text { Unit } 1 \\
\text { Know More about } \\
\text { Credit Cards (CC) }\end{array}$ & $\begin{array}{l}\text { To understand consumer loans (e.g., } \\
\text { using credit cards) rationally }\end{array}$ & $\begin{array}{l}\text { (1) To understand the financial burden and risks caused } \\
\text { by consumer loans } \\
\text { (2) To reflect if there are alternatives to consumer loans }\end{array}$ \\
\hline $\begin{array}{l}\text { Unit } 2 \\
\text { The Kindest Cut } \\
\text { (SP) }\end{array}$ & $\begin{array}{l}\text { To deepen students' understanding } \\
\text { towards meaning of life through the } \\
\text { discussion on vocation }\end{array}$ & $\begin{array}{l}\text { (1) To introduce Dr. Sydney Sheung-Chee Chung's } \\
\text { work and worldview and probe into the conditions of } \\
\text { ideal work } \\
\text { (2) To deepen students' understanding about the } \\
\text { relationship between money and success and reflect on } \\
\text { the meaning of life }\end{array}$ \\
\hline \multirow[t]{2}{*}{$\begin{array}{l}\text { Unit } 3 \\
\text { Welcome } \\
\text { Everybody to the } \\
\text { Party! (SE) }\end{array}$} & \multirow[t]{2}{*}{$\begin{array}{l}\text { To help students understand the } \\
\text { method of budgeting and how the } \\
\text { styles of consumptions can } \\
\text { contribute to making meaningful } \\
\text { changes and leading to a better world }\end{array}$} & $\begin{array}{l}\text { (1) To nurture students' ability of goal achievement } \\
\text { and attitude and skills of good financial management } \\
\text { (2) To enhance students' knowledge of responsible } \\
\text { consumption with local examples and establish } \\
\text { students' belief in civil responsibility with the practice } \\
\text { in consumption }\end{array}$ \\
\hline & & $\begin{array}{l}\text { (3) To encourage students to use the knowledge, skills, } \\
\text { and attitude taught in this chapter in real school life }\end{array}$ \\
\hline
\end{tabular}

Notes: CC: cognitive competence, SE: self-efficacy, SP: spirituality.

assist them to enhance their willingness to search for the meaning of life. This could be a good means to enable them to make career decisions with confidence and to manage money in a more meaningful way.

\section{THE OBJECTIVES AND DESIGN OF THE CURRICULUM UNITS}

In the newly designed P.A.T.H.S. curriculum for secondary 3, three units on Money and Success have been designed. The goals are to help students develop their critical thinking skills, understand their meaning of life, and to enhance their self-efficacy. Since these three teaching units were composed to promote among the participants the three selected positive youth development constructs we discussed in this paper, they are therefore taken as examples to illustrate the design of the program. Unit 1 is designed to develop students' Cognitive Competence while Unit 2 and Unit 3 are designed to develop students' Spirituality and SelfEfficacy, respectively. The aims and learning targets of these three units are presented in Table 2.

Unit 1. This unit is to develop students' cognitive competence in order to assist them to understand the risk of using credit cards. By participating in a competition activity, students would concretely experience more about the costs and financial risks of using credit cards. This could enhance students' knowledge of financial products and their ability in evaluating the reliability of the related information they got, hoping to foster their critical thinking in financial decisions. Critical thinking is a process involving careful and logical induction to determine what kind of information to accept and what appropriate actions to take [24, 31]. This unit also provides students with alternatives other than using credit expenses. This would cultivate their divergent thinking and hopefully promote their creativity as well.

Unit 2. Being a secondary 3 student in Hong Kong, he/she has to choose the areas for study and consider the path for his/her career development. Therefore, the second unit of "Money and Success" is to foster students' spirituality that encourages them to look ahead of their career goal by considering the definition of success and the meaning of life. In this unit, a true story of a medical professor, Dr. Sydney SheungChee Chung, the former Dean of the Medicine Faculty of a university in Hong Kong, who gave up the high 
income and the prestigious position as the dean and took up the challenge to work for a third world country is revealed. In the interview with Dr. Chung, he shared his gain and loss from his altruistic action as well as his views on humanistic values. This story serves as a means to stimulate students to think about their ideal, life meaning, and career decision, hoping that this could help students form a basis to consider their future career choice and to plan their long-term career goals from a wider perspective.

Unit 3. This unit aims to enhance students' self-efficacy in money management. According to Chung [32], junior-form students in Hong Kong might have developed a utilitarian attitude in money expenses. Therefore, in this unit, students are encouraged to develop a habit of planning their expenses in a creative way in order to meet different ends with financial constraints. Budgeting skills are the focuses of this unit. Students are invited to plan their expenses of a class party by considering "ethical consumption," their sense of responsibility, and the financial situation they are in. It is hoped that we can foster students' confidence in spending every dollar in a responsible way. "Ethical consumption" is also named "responsible consumption" which is defined as "a person basing his or her acquisition, usage, and disposition of products on a desire to minimize or eliminate any harmful effects and maximize the long-run beneficial impact on society" [33, page 47]. The willingness to spend more to buy recycling products in order to protect the environment is one example of ethical consumption.

\section{A CONCLUDING REMARK}

The design of the three new teaching units related to money management for secondary 3 students in Hong Kong has been introduced. We would like to emphasize again that the focus of the units is on promoting students' development of the selected constructs and psychosocial competence rather than on only promoting their money management skills or develop the related values and attitudes towards money and success. One may query that in the second phase of Project P.A.T.H.S., only nine teaching units designed for the junior secondary forms might not be enough to form a strong curriculum to enhance the financial skills of secondary 1 to secondary 3 students. However, these nine teaching units are only part of the comprehensive P.A.T.H.S. curriculum for promoting students' positive youth development. It is our belief that enhancing adolescents' positive youth development could well equip them to face their life issues in a more effective way.

\section{ACKNOWLEDGMENT}

The preparation for this paper and the Project P.A.T.H.S. were financially supported by The Hong Kong Jockey Club Charities Trust.

\section{REFERENCES}

[1] R. F. Catalano, M. L. Berglund, J. A. M. Ryan, H. S. Lonczak, and J. D. Hawkins, "Positive Youth Development in the United States: Research Findings on Evaluations of Positive Youth Development Programs," 2002, http://aspe.hhs.gov/hsp/PositiveYouthDev99/.

[2] D. T. L. Shek and R. C. F. Sun, "Development, implementation and evaluation of a holistic positive youth development program: project P.A.T.H.S. in Hong Kong," International Journal on Disability and Human Development, vol. 8, no. 2, pp. 107-117, 2009.

[3] D. T. L. Shek, H. K. Ma, and R. C. F. Sun, "Development of a new curriculum in a positive youth development program: the project P.A.T.H.S. in Hong Kong," TheScientificWorldJournal. In press.

[4] N. Dowling, L. Hoiles, T. Corney, and D. Clark, "Financial management and young Australian workers," Youth Studies Australia, vol. 27, no. 1, pp. 26-35, 2008.

[5] N. S. Godfrey, "Making our students smart about money," Education Digest: Essential Readings Condensed for Quick Review, vol. 71, no. 7, pp. 21-26, 2006. 
[6] K. Y. Cheng, "One tertiary institute student found in five indebted youths," Wen Wei Po, 2010, http://paper .wenweipo.com/2010/07/07/HK1007070010.htm.

[7] P. S. F. Yip, K. C. T. Yang, B. Y. T. Ip, Y. W. Law, and R. Watson, "Financial debt and suicide in Hong Kong SAR," Journal of Applied Social Psychology, vol. 37, no. 12, pp. 2788-2799, 2007.

[8] R. Y. K. Chan, "Banking services for young intellectuals," International Journal of Bank Marketing, vol. 11, no. 5, pp. 33-40, 1993.

[9] A. W. Chau, S. F. Chan, and Y. Chan, Study on Financial Management Practices of University Students in Hong Kong, Tung Wah Group of Hospitals \& General Education Unit, University of Hong Kong, Hong Kong, 2004.

[10] L. Mandell and L. S. Klein, "The impact of financial literacy education on subsequent financial behavior," Journal of Financial Counseling and Planning, vol. 20, no. 1, pp. 15-24, 2009.

[11] L. Mandell, Financial Literacy: Are we Improving? Results of the 2004 National Jump\$tart Survey, Jumpstart Coalition, Washington, DC, USA, 2004.

[12] L. Mandell and L. S. Klein, "Motivation and financial literacy," Financial Services Review, vol. 16, pp. 106-116, 2007.

[13] L. A. Koenig, "Financial literacy curriculum: the effect on offender money management skills," Journal of Correctional Education, vol. 58, no. 1, pp. 43-56, 2007.

[14] T. Stanger, "Future debtors of America," Consumer Reports, vol. 62, pp. 16-19, 1997.

[15] P. McCrystal, A. Percy, and K. Higgins, "The cost of drug use in adolescence: young people, money and substance abuse," Drugs: Education, Prevention and Policy, vol. 14, no. 1, pp. 19-28, 2007.

[16] S. M. Danes, "Parental perceptions of children's financial socialization," Journal of Financial Counseling and Planning, vol. 5, pp. 127-149, 1994.

[17] S. Ward, "Consumer socialization," Journal of Consumer Research, vol. 1, pp. 1-16, 1974.

[18] A. Atkinson, S. McKay, E. Kempson, and S. Collard, "Levels of Financial Capability in the UK: results of a baseline survey. UK: financial Services Authority," 2006, http://www.fsa.gov.uk/pubs/consumer-research/ crpr47.pdf.

[19] C. Y. Kwok and L. P. Yung, A Teacher's Handbook of "Financial Capability": A Practical Educational Project, Caritas Family Crisis Support Centre, Hong Kong, 2005.

[20] A. Kezar and H. Yang, "The importance of financial literacy," About Campus, vol. 14, pp. 15-21, 2010.

[21] D. T. L. Shek, "Evaluation of project P.A.T.H.S. in Hong Kong: triangulation of findings based on different evaluation strategies," TheScientificWorldJournal, vol. 8, pp. 1-3, 2008.

[22] R. C. F. Sun and E. K. P. Hui, "Cognitive competence as a positive youth development construct: conceptual bases and implications for curriculum development," International Journal of Adolescent Medicine and Health, vol. 18, no. 3, pp. 401-408, 2006.

[23] R. J. Sternberg and T. I. Lubart, “An investment theory of creativity," Human Development, vol. 13, pp. 1-32, 1992.

[24] R. H. Ennis, Critical Thinking, Prentice Hall, Saddle River, NJ, USA, 1996.

[25] A. Bandura, Social Foundations of Thought and Action, Prentice-Hall, New York, NY, USA, 1986.

[26] J. E. Maddux and J. T. Gosselin, "Self efficacy," in Handbook of Self and Identity, M. R. Leary and J. P. Tangney, Eds., Guilford Press, New York, NY, USA, 2003.

[27] A. Bandura, "Self-efficacy," in Encyclopedia of Human Behavior, V. S. Ramchaudran, Ed., vol. 4, pp. 71-81, Academic Press, New York, NY, USA, 1994.

[28] S. K. M. Tsang and E. K. P. Hui, "Self-efficacy as a positive youth development construct: conceptual bases and implications for curriculum development," International Journal of Adolescent Medicine and Health, vol. 18, no. 3, pp. 441-449, 2006.

[29] P. S. Y. Lau, "Spirituality as a positive youth development construct: conceptual bases and implications for curriculum development," International Journal of Adolescent Medicine and Health, vol. 18, no. 3, pp. 363370, 2006.

[30] P. C. Cheung, H. K. Ma, and D. T. L. Shek, "Conceptions of success: their correlates with prosocial orientation and behaviour in Chinese adolescents," Journal of Adolescence, vol. 21, no. 1, pp. 31-42, 1998.

[31] D. E. Flage, The Art of Questioning: An Introduction to Critical Thinking, Pearson, NJ, USA, 2004. 
[32] K. W. Chung, "Financial management education for children should be essential," in A Teacher Handbook of "Financial Capability”: A practical Educational Project, C. Y. Kwok and L. P. Yung, Eds., p. 2, Caritas Family Crisis Support Centre, Hong Kong, 2005.

[33] L. A. Mohr, D. J. Webb, and K. E. Harris, "Do consumers expect companies to be socially responsible? The impact of corporate social responsibility on buying behavior," Journal of Consumer Affairs, vol. 35, no. 1, pp. 45-72, 2001.

\section{This article should be cited as follows:}

Patrick S. Y. Lau, C. M. Lam, Ben M. F. Law, and Y. H. Poon, “Using Positive Youth Development Constructs to Design a Money Management Curriculum for Junior Secondary School Students in Hong Kong," TheScientificWorldJOURNAL, vol. 11, pp. 2219-2229, 2011. 